\title{
Biomolecular Methods for Analyses of Apple Allergens
}

\author{
K. Takács ${ }^{1}$, J. Szamos ${ }^{1}$, E. E. Szabó ${ }^{1}$, E. Kovács ${ }^{2}$ and É. Gelencsér ${ }^{1}$ \\ ${ }^{1}$ Central Food Research Institute, Department of Biology, H-1022 Budapest Herman Ottó út 15, Hungary and ${ }^{2}$ Corvinus \\ University of Budapest, Faculty of Food Science Department of the Postharvest Science and Technology, H-1118 Budapest \\ Ménesi út 45/F, Hungary
}

Apple (Malus domestica) is involved in a healthy, well-balanced diet but some sensitive people can react with severe immunologic reactions to this fruit. While the prevalence of apple allergy in food allergic patients is generally below $2 \%$, apple allergy is most frequently is associated with birch pollinosis in Northern Europe where $40-90 \%$ of these patients are sensitized to apple allergens. The main allergens in apple are Mal d 1, d 2, d 3, d 4 proteins, so their properties and distribution in the fruit, and the effect of different physical and chemical treatments on them are intensively studied. Previous studies have indicated that the expression pattern of Mal $\mathrm{d}$ allergens is affected by growing and storage circumstances. Mal d 1 and Mal d 4 allergens are heat labile allergens at room temperature and sensitive to proteolytic degradation, while Mal d 2 and Mal d 3 allergens are resistant to heat and stable to proteolytic degradation. Mal d 1 and the Mal d 2 proteins are the significant apple allergens inducing IgE-mediated hypersensitivity reaction.

Our target allergens were Mal d $1(18 \mathrm{kDa})$ and Mal d $2(31 \mathrm{kDa})$ proteins to isolate from natural source and develop a novel bioanalytical method for quantification of these major allergens in different apple cultivars. The purified Mal $\mathrm{d}$ allergens were used for antibody development and as inside standards.

Simultaneous extraction and isolation of Mal d 1 and Mal d 2 allergens has raised some methodological problems. Because of the instability of Mal d 1 protein there is no reliable purification and quantification methods so far from the from natural sources while there are more references available on purification of Mal d 2.

A novel approach was applied for the common extraction and purification of the target allergenic proteins. To inhibit the strong interaction between the protein and phenolic compound during enzymatic browning, acidic extraction (from frozen pulp) was applied. The extract was used for tracking and quantitative distribution of these proteins by the means of cation exchange chromatography and following gel filtration chromatography. These results were confirmed by Mal d 1 and Mal d 2 specific ELISAs developed on the bases of target specific polyclonal antibodies produced in rabbit.

As a general rule, the apples showed different allergenic profile in cultivars. Generally, it was found that during the ripening period, the contents of Mal d 1 and Mal d 2 allergens in apple cultivars were continuously increased in different extend. The content of Mal d 1 $(0.1-0.25 \mathrm{mg} / 100 \mathrm{~g}$ apple) in Golden Delicious has increased intensively from the day of 144 until the day of 152 then the raise has stopped between the days of 152 and 164 , while the content of Mal d $2(0.18-0.75 \mathrm{mg} / 100 \mathrm{~g}$ apple) has raised continuously from the day of 144 until the day of 158 according to the chromatographic results. ELISA results showed the same tendency.

The highlight of this study is that a liquid chromatographic method was developed to purify apple allergens as Mal d 1 and Mal d 2. The main advantage of this method was the reduction of the loss of Mald 1 protein by acidic extraction procedure at low temperature which made this method suitable for monitoring the Mal d 1 and Mal d 2 apple allergens simultaneously.

Such examinations of apple allergens like the above mentioned are important in order to give information for apple allergic patients to avoid the allergy-causing cultivars. Moreover we can draw the plant breeders' attention to the possibility for cultivating apple species with lowered allergenic risk. 